\title{
Multi-Dimensional Values on Customers' Intention to Revisit Green Resorts: The Cultural Case in Malaysia
}

\author{
Nor Rabiatul Adawiyah Nor Azam*, Basri Rashid', Noor Azimin Zainol', Maliani Mohamad²
}

${ }^{1}$ School of Tourism, Hospitality and Event Management, University Utara Malaysia, Malaysia

${ }^{2}$ School of Business Management, University Utara Malaysia, Malaysia

*Correspondence to: rabiatulnorazam@gmail.com

\begin{abstract}
This study investigates the concept of perceived value on the customers' intention to revisit Malaysian green resorts. It is a cultural case that happened in Malaysia. The perceived value would be assessed in a formative manner based on a multi-dimensional scale, which includes the dimensions of functional, social, emotional, and epistemic. This research was applied to a survey method. The unit of analysis is the resort customers, with distributed questionnaires to customers who have stayed in one of the selected green resorts and have consumed the products and services at these resorts for at least two days. This study provides significant insights and pertinent recommendations to the hospitality industry and extends the existing body of knowledge by assessing perceived value as an integrated formative construct and examining customers' overall perceived value towards green resorts. This study provides an in-depth understanding of the importance of green resorts associated with the communities, groups, and individuals from one generation to the next. Also, this study can be a benchmark, provide guidance, and the basis for future directions of future studies that are similar. It can contribute to providing a broader perspective on the issue. This study also addresses what academicians can do to teach students in the field of hospitality and tourism, create awareness among individual consumers and finally, to promote sustainability for tourists, travelers, as well participants in the field of hospitality. Next, attention is also given to the teaching of the hospitality and tourism areas in the lodging, meetings and events, and foodservice segments of the industry. Sustainability education in lodging operations includes ensuring that students understand that "green" lodging professionals participate. The paper estimates the demand for customers' intention to revisit the green resort in Malaysia. The originality of this paper comes out to the need to identify the application of green initiatives in the hospitality industry continues to rise in their contribution to preserve the environment as well as meeting the demands of environmentally-conscious customers.
\end{abstract}

Keywords: Perceived Value; Functional Value; Social Value; Emotional Value; Epistemic Value; Green Resorts

Recommended citation: Azam, N. R. A. N., Rashid, B., Zainol, N. A., \& Mohamad, M. (2020). Multi-Dimensional Values on Customers' Intention to Revisit Green Resorts: The Cultural Case in Malaysia. Journal of Innovation in Educational and Cultural Research, 1(2), 41-51

\section{INTRODUCTION}

The quality of the environment largely influences the hospitality industry as tourists travel over great distances to experience exotic and unpolluted environment. Resort hotels are among the fastest-growing segments of tourism attractions and are rapidly growing in number, diversity, and popularity. The global resort industry, which was previously in the depths of a recession, has steadily recovered and proliferated, particularly over the last four years (Ibisworld, 2013). This growth could be observed in the Malaysian tourism industry. Many travels to resort hotels located at enthralling destinations to divert themselves from mundane routines and to experience enjoyment (Yang \& Chan, 2010; Ali et al., 2013). It has contributed to the dominance of resort hotels in the accommodation industry (Inkabaran et al., 2004). The customers and their first-rate perceived value are the primary focus of this industry to sustain customers' loyalty and favorable behavioral intentions (Hu et al., 2009).

Meanwhile, the movement towards sustainability propels many businesses to adopt green practices through the development of services and products. The term "green" signifies "environmentally friendly" (Shrum, 2005). In the context of the hospitality industry, the demands for green establishments among customers have been gradually increasing due to the environmental damages and uncontrollable consumption of environmental resources such as energy, natural resources, and non-recyclable goods (Dief \& Font, 2010). Therefore, customers opt for resort hotels that adopt green practices. It compels the hospitality industry to incorporate green practices into the services and products provided. Accordingly, these green practices include recycling, reducing waste, water conservation, and clean air practices (Bohdanowicz, 2006), which directly affect the operating costs and overall performance of these resort hotels. 
Customers' perceived value reflects the performance of these resort hotels. Hence, providing first-rate customer value, particularly in terms of customers' needs and desires, is vital to maintain a competitive advantage. Nonetheless, there are various definitions of customer value (Zeithaml, 1988). Customer value could be expressed as the mental images or cognitive representations that underlie customers' needs and goals (Wilkie, 1994), which ultimately affects customers' responses in specific situations (Schiffman \& Kanuk, 1987). Zeithaml (1988) viewed perceived value as "consumer's overall assessment of the utility of a product or service based on perceptions of what is received and what is given" (p.14).

Recent studies have elucidated the significance of customers' perceived value regarding their satisfaction towards the tourism destinations because it influences their choice of destination and their decision to revisit (Kozak \& Rimmington, 2000; Yoon \& Uysal, 2005). Essentially, customers' perceived value primarily determines their behavior. There have been various studies to grasp the origin of customers' perceived value towards a specific destination of choice. There are various interpretations on the concept of perceived value where (1) it is regarded as a prevailing belief towards a specific aspect as more desirable than other aspects; or (2) as evaluation criteria; or (3) as a utility, which is acquired from experiencing the consumption. Fundamentally, the value itself reflects one's attachment to a specific thing that forms a particular personal judgment, whether it is favored and to what extent. In other words, the consumption of services or products creates multi-dimensional outcomes (Holbrook, 1999; Sandstrom et al., 2008), which subsequently contribute to various dimensions of consumption values for these products or services (Sheth et al., 1991; Williams \& Soutar, 2000). As Jamal et al. (2011) described, perceived value is a function of the feelings and attitudes of customers about a specific product obtained, or service experienced. Overall, it is pivotal to have an improved understanding and prediction of the customers' intentions to revisit specific destinations.

Over the recent years, there has been a growing research interest on the role of customers' perceived value in explaining environmental management and practices, the green strategies related to environmental policies, and the customers' attitudes and preferences towards green practices. Meanwhile, the customers' perceived functional and emotional values during their stay at a green hotel were also explored (Fu \& Hu, 2011). However, no empirical study has been conducted to develop an in-depth understanding of the concept of perceived value in the context of the green resort.

This study focuses on how perceived value influences customers' intention to revisit green resorts. Specifically, this study proposes four consumption values: functional value, social value, emotional value, and epistemic values as the antecedents to customers' intention to revisit green resorts. This study also provides the ranking of the importance of these value dimensions from the customers' perspective. The evaluation of customers' perceived value in the context of green resorts would provide significant insights on these visits to the host providers and marketers, which allows them to assess how the customers' experience in green resorts could be improved across different dimensions of value.

The term "green" refers to the actions of reducing negative impacts on the environment, such as ecopurchasing or recycling (Han et al., 2011). Meanwhile, the term "green resorts" refers to environmentally friendly lodgings that adopt various green practices such as energy and water conservation, solid waste minimization, recycling practices, and reuse of durable service items for environmental conservation (Green Hotel Association, 2008). Thus, given the growing awareness on the potential of going green as an added value to gain competitive advantages in the hospitality industry, related stakeholders take a proactive approach to develop appropriate strategies in creating an environmentally friendly business (Manaktola \& Jauhari, 2007).

The hospitality industry plays a pivotal role in boosting the economy of Malaysia. Undeniably, the industry also potentially deteriorates the quality of the environment, which explains the growing environmental concern globally. In Malaysia, 7.34 million tons of solid waste are generated annually, where the hospitality industry is one of the contributors to this environmental issue (Ramayah et al., 2010). Considering that this industry utilizes a substantial amount of both consumer and non-durable goods, the high generation of solid waste is likely to occur. As revealed by Pirani and Arafat (2014), a single customer in a green resort generates at least $1 \mathrm{~kg}$ of solid waste per day, where recyclable materials constitute approximately $50 \%$. Therefore, this has led to an increase in the number of green resorts (Hsiao et al., 2014).

The need to adopt a "green resort" strategy is widely recognized over recent years. This current study focuses specifically on green resorts rather than green hotels because this type of resorts is considered one of the perfect tropical beach destinations because of their stunning beaches and abundant flora and fauna. All these green characteristics often appeal to outdoor explorers and nature lovers. Visitors can engage in various activities that bring them closer to nature when staying at these resorts. Resorts are one of the fastest-growing segments of tourism attractions and are rapidly growing in number, diversity, and popularity since the economic boom in the 1960s. Today, a large number of people travel to resorts situated in exotic and beautiful destinations in order to enjoy themselves and escape from their daily routine (Yang \& Chan, 2010 ). Rahman (2012) mentioned that "location has an impact on hotel environmental practice" (p. 722). Location in a natural setting is one of the 
driving factors for resorts operators to become competitive in minimizing and eliminating their operation externalities on the environment.

One of the typical strategies adopted by resort hotels globally is the establishment of monitoring systems and standards, which are utilized to monitor the consumption of energy and water and the generation of solid waste. For instance, the strategy is particularly useful for the resort hotel to identify which facility has the highest energy consumption in terms of lighting where the energy use of lighting in that specific facility could be adjusted according to a specified target of, for example, $20 \%$, over a specified duration of time or replace these lighting with compact fluorescent lighting. The concepts of "environment protection" and "energy saving" encourages these resort hotels to adopt green management, which benefits the environment as well as reduces the resort hotels' operation costs. Essentially, the concept of green resorts provides immense potential and opportunities to not only reduce the environmental impacts and the consumption of energy but also to provide first-rate green services and products to customers.

This current research focuses specifically on green resorts rather than green hotels because this type of resorts is considered one of the perfect tropical beach destinations because of their stunning beaches and abundant flora and fauna. All these green characteristics often appeal to outdoor explorers and nature lovers. Visitors can engage in various activities that bring them closer to nature when staying at these resorts. Resorts are among the fastest-growing segments of tourism attractions and are rapidly growing in number, diversity, and popularity since the economic boom in the 1960s. Today, a large number of people travel to resorts situated in exotic and beautiful destinations in order to enjoy themselves and escape from their daily routine (Yang \& Chan, 2010). Ramayah (2012) mentioned that "location has an impact on hotel environmental practice" (p. 722). Location in a natural setting is one of the driving factors for resorts operators to become competitive in minimizing and eliminating their operation externalities on the environment.

Perceived value is considered one of the most integral concepts in understanding customers of the service industry. Perceived value distinguishes a specific service or product among the competitors where its value is determined accordingly by customers (Zeithaml, 1988). Accordingly, customers relate their previous experiences with different types of service or product and envisage these experiences, which subsequently affect their present and future experiences of the value-in-context. Cronin et al. (2000) implied that perceived value itself is a significant predictor of customer satisfaction and behavioral intentions. Sheth et al. (1991) identified a 5dimensional value comprised of functional value, social value, emotional value, epistemic value, and conditional value. Following that, Sweeney and Soutar (2001) developed a multi-dimensional scale inclusive of functional (economic and quality), emotional, and social dimensions. Meanwhile, Jamal et al. (2011) employed another multidimensional scale to examine perceived value among tourists in homestays, which included dimensions of functional (price and establishment), experiential (activity, culture, knowledge, and hotel guest interaction), and emotional value.

On the contrary, Lee et al. (2011), Barber (2012), and Yang \& Youngtae (2015) asserted that the four dimensions for perceived green benefits (functional, social, emotional, and epistemic benefits) were not significant predictors of purchase intention mainly. Besides functional and emotional benefits, monetary and explicit costs are significantly associated with purchase intention. Given its situational characteristic, the formation of value perception could be influenced by various factors. Holbrook and Corfman (1985) argued that the value referred to different things at different times, such as purchasing, preparation, and consumption. In the marketing literature, the perceived value has been characterized as the key to explaining customers' behaviour (Petrick, 2004).

Nevertheless, the perceived value towards the destination of choice remains not well explored (Chen \& Tsai, 2007; Pandža, 2013). Valid and reliable measures of perceived value allow customers to identify the dimensions of perceived value they experience. With that, this study proposes a conceptual model for improved understanding of the role of these four consumption values (functional value, social value, emotional value, and epistemic value), which are expected to influence customers' intention to revisit green resorts.

Functional value refers to "the perceived utility acquired from an alternative's capacity for functional, utilitarian, or physical performance" that reflects the quality of the physical outcome for using a specific service or product on a series of salient attributes such as price, reliability, and durability (Sheth et al., 1991). In the context of the hospitality industry, the functional value could be acquired from the consumption of physical aspects (natural or human-made), services, and products at a specific destination such as souvenirs, food, and various activities (Morgan et al., 2010). Comfort, prices, quality, reliability, safety, and variety are some of the primary factors associated with functional value. Green practices such as using non-toxic materials, replace plastic utensils to glassware, or serving organic food in green resorts, not only reduce the environmental impacts, but also provide the first-rate experience for customers in terms of health and safety with improved air quality, eco-friendly linens, and considerations for allergy sufferers (Kim et al., 2011; Lee et al., 2011).

Social value refers to the perceived utility acquired through the consumption of an alternative as a result of its association with one or more specific social groups, which represent demographics that may be similar to the 
customers, either in terms of socioeconomic, cultural, or ethnic dimensions (Sheth et al., 1991). Maibach (1993) argued that customers would be motivated if their environmental contributions are acknowledged or admired by others. Therefore, social value plays a significant role in developing customers' perceptions based on their experiences (Williams \& Soutar, 2000; Morgan et al., 2010). It is acquired when one is socially approved, feels accepted, makes a good impression on others, and improves oneself (Sweeney \& Soutar, 2001). In the hospitality industry, the social value could also be related to direct social interactions. Examples of factors that contribute to social value are the friendliness and hospitality, respectful treatment, genuine care for customers, and the willingness of others to help (Noypayak, 2009). Accordingly, customers who display their environmental consciousness and expect to be recognized exhibit a type of auto-expression emotion perceived as a "statusenhancing" benefit (Griskevicius et al., 2010). For some, opting for green resorts creates a positive impression on other people (Barber, 2012).

Emotional value refers to the emotional evaluation of a particular service or product derived from the perceived capability of attributes to arouse a specific feeling or affective state, which, in turn, drives the behavior (Tapachai \& Waryzak, 2000). Green consumption is compatible with environmental conservation, which generates positive feelings (Corall-Verdugo et al., 2009). The overall feeling of well-being is associated with altruism (Ritov \& Kahnemann, 1997), which is said to be doing something good for others without expecting anything in return (Jeong \& Jang, 2010). A growing desire for improved well-being has emerged as an essential emotional benefit among customers who opt for green resorts (Robinot \& Giannelloni, 2010). They sensed that their decision contributes to environmental sustainability (Hotel Online, 2002). Russell and Pratt (1980) suggested four primary emotional states (pleasant, unpleasant, arousing, and sleepy), which help evaluate tourist destinations, whether exciting, relaxing, irritating, or dull. To measure the emotional value, Sweeney and Soutar (2001) deployed scale items such as feeling relaxed, enjoying consumption, and receiving pleasure.

Meanwhile, Petrick (2002) noted that the consumption should make customers feel good and delighted, provide pleasure and a sense of joy, and bring happiness to create emotional value. In the context of green resorts, emotional benefits such as altruism or intrinsic motivation of well-being were proven to be significant predictors of environmentally friendly activities (e.g., recycling) and green consumerism (Griskevicius et al., 2010; Barber, 2012). Besides, the green certification was also seen as a sign of quality, which contributed to customers' tendency to choose or pay (Millar \& Baloglu, 2011).

Epistemic value relates to the surprise or novelty aspect of a service or product provided, which subsequently offers customers to experience novelty or satisfies their desire for knowledge (Sheth et al., 1991). However, despite the role of green resorts in providing environmental education for their customers, this dimension of value has not been sufficiently explored in green resorts (Kotler et al., 1999). Essentially, epistemic value is one of the core benefits expected from customers in the hospitality industry (Williams \& Soutar, 2009). Experiencing diverse lifestyles and socio-cultural environments, meeting new people, trying new food, and learning and discovering are among the strongest motivations to travel (Andreu et al., 2006; Kim et al., 2007).

The formation of value perception is very situational and can be influenced by many factors. Holbrook and Corfman (1985) argued that value meant different things at different times, such as at the points of purchase, preparation, and consumption. Resort managers need to change and adapt their product and service to create new and novel experiences for tourists to ensure they obtain epistemic value. In a green research context, the epistemic value can be claimed as a customer's desire for knowledge and experiencing new and different lifestyles with the green concept to meet new people, try a green product and service, and learning and discovering the green resorts facilities.

"Intention" indicates one's willingness to engage in the said behavior. The customers' intention to revisit a destination may be influenced by the perceived value of the destination along with the performance, the promotional efforts, and the information dissemination on the new attractions. Meanwhile, the "intention to revisit" refers to customers' previous experiences perceived as highly valuable in terms of costs and efficiency, which contribute to their tendency to revisit (Ha \& Jang, 2010).

In the service sector, Han et al. (2009) and Han et al. (2010) specifically analyzed customers' intention to revisit, to recommend, and willingness to pay more for green resorts. Meanwhile, Han and Kim (2010) examined the influence of customers' satisfaction on their intention to revisit green resorts. Based on the interrelationships of destination image, evaluative factors (trip quality, perceived value, satisfaction), and behavioral intentions, Chen and Tsai (2007) concluded that "perceived value does play an important role in affecting the level of satisfaction and future behavioral intentions of customers" (p. 1,121).

Meanwhile, Um et al. (2006) identified the relative weight of tourist evaluation constructs to the customers' intention to revisit. Based on the survey on the pleasure tourist in Hong Kong, they found that the intention to revisit was primarily determined by what they perceived from the performance of the destination compared to their satisfaction level. The utilization of perceived value in predicting customers' intention to revisit contributes to improved understanding of customers' after-decision-making behaviors. On the other hand, Kuo et al. (2009) 
constructed a model to evaluate the mobile service quality in the value-added services provided and explored the interrelationships of customer service quality, perceived value, satisfaction level, and post-purchase intention. The perceived value was found to influence customers' post-purchase intentions positively. On the other hand, Yang and Youngtae (2015), who investigated the perceived value in the pre-purchase stage, found that their behavioural intention was only reflected by their willingness to choose a green resort.

Fundamentally, the customers' intention to revisit is affected by various factors, and the customers' perceived value plays a crucial role in determining customers' intention to revisit and their decision to revisit. In short, customers' perceived value is expected to be positively related to customers' intention to revisit green resorts, given that they would re-evaluate the value of green resorts after experiencing them. The majority of customers depend on their past experiences on whether they intend to revisit green resorts.

Based on the previous literature, a research framework is proposed concerning the objectives of this study with the consideration of four independent variables (functional value, social value, emotional value, and epistemic value) and one dependent variable (customers' intention to revisit green resorts), as illustrated in Figure 1. In this context, functional value, social value, emotional value, and epistemic value are expected to influence customers' intention to revisit.

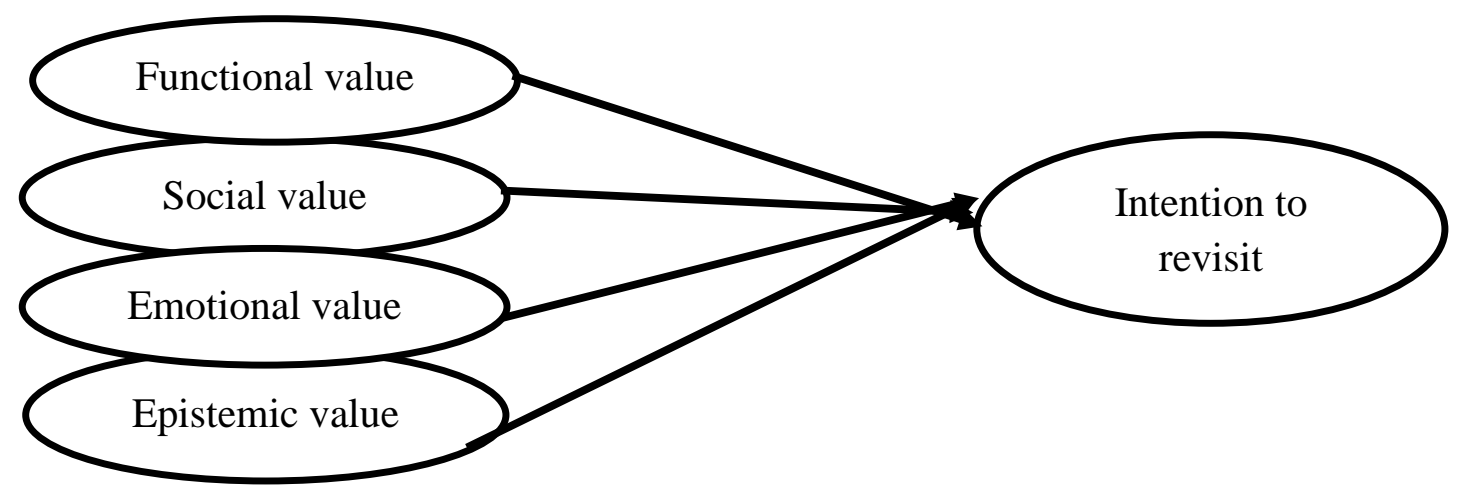

Figure 1. The research framework of Multi-Dimensional Values on Customers' Intention to Revisit Green Resorts

Because of the reviewed literature, the following hypothesis is developed for the study.

H1: Multi-dimensional value would influence customers' intention to revisit green resorts.

H1a: Functional value would influence customers' intention to revisit green resorts.

H1b: Social value would influence customers' intention to revisit green resorts.

H1c: Epistemic value would influence customers' intention to revisit green resorts.

H1d: Emotional value would influence customers' intention to revisit green resorts.

\section{METHODS}

The research design refers to a plan, structure, or strategy to acquire answers to the objectives or research questions. This study employed a questionnaire survey design to observe the trend of a large population of individuals based on their attitudes, opinions, and behaviors. The subsequent section describes the employed research design, including the development of the instrument. Accordingly, this study considered the quantitative method as the most appropriate method to assess the relationships between measurable constructs. The quantitative approach is deemed to be essential in analyzing and proving theories and identifying potential constructs and relationships. Most importantly, the quantitative method applies legal validity and reliability tests and appropriate statistical procedures. Besides, using a quantitative approach is deemed appropriate in testing the proposed conceptual model across a more comprehensive sample of the population of interest.

\section{Participants}

The population refers to the whole group of people or organizations of interest in a study. The targeted population serves as the source from which the data should be gathered, influencing the quality of results and findings. Accordingly, this study targeted the green resort guests in the selected green resorts, namely Frangipani Beach Resort and Spa Langkawi (Kedah), Shangri-La's Rasa Sayang Resort and Spa (Penang Island), and Holiday Inn Resort (Penang Island). This study selected these three green resorts because these resorts were awarded the ASEAN Green Hotel Award for three consecutive years (2016-2018) at the ASEAN Tourism Forum in Manila, Philippines. 
This study selected Langkawi Island and Penang Island as the sampling locations because these locations are popular beach resort destinations in Malaysia, rich in cultures, and the hotspot for prominent green resorts. Conducting the study in these sampling locations was deemed feasible as the obtained results and findings were expected to benefit the current and future hotel and resort operators in their efforts to go green for their business operation. Meanwhile, selecting these sampling locations for this study would facilitate other resorts to attain the standards of green resort, strengthen their competitiveness in environmental protection measures, and enhance the green aspects of their business operation.

\section{Instrument}

The scale design for the questions adopted the Likert-type scale. This practice is widely utilized by consumer-related and tourism-related studies, particularly in those that require perception responses. Notably, using a Likert-type scale with five and seven points is expected in tourism-related studies, particularly those related to destination evaluation. Arguably, the seven-point scale offers more possibility for the respondent to select the answers, and it provides a broader range of magnitude for the answers. Hence, the selections of answers are made more manageable, and the chances of obtaining more reliable answers are increased.

Due to these reasons, this study decided to implement a seven-point scale measurement in the questionnaire. A multi-item seven-point scale was adopted: Score of "1" was depicted as strongly disagree up to "7" as strongly agree. Five variables presented for measurement the revisit intention were environmental awareness, functional value, social value, emotional value, and epistemic value. The items were adopted from Yang and Youngtae (2015), Sweeney, and Soutar (2001).

\section{Data Collection}

The data for this study were collected using a questionnaire survey and distributed to 450 customers who have stayed in one of the selected green resorts and have consumed the products and services at three green resorts in Langkawi and Penang Island, Malaysia for at least two days. A structured questionnaire was designed to measure the variables to capture the necessary information for the research question and relevant hypotheses. This section explains the details of the questionnaire designed for this study. The main objective of the questionnaire was to discover what the respondents thought or felt about certain situations, conditions, and issues.

There were two phases in the distribution and collection of the questionnaires. The first phase of the data collection was the pilot test, to reduce the risk of missing possible alternative answers and to adjust any inappropriate words, statements, or description in the questionnaire. In the second phase, the primary method to collect the data was to distribute questionnaires at the beach resort in the morning and the evening during the period when guests were generally more relaxed. Since it was relatively less hot, many took this time to enjoy flora and fauna. Due to that, the customers were assumed to be more willing to answer the questionnaires. The opportunity was also apt to establish if the customers had stayed for at least two nights.

\section{Data Analysis}

This study primarily focused on the direct relationship between perceived value and revisit intention. This study conducted reliability analysis, descriptive analysis, factor analysis, and regression analysis using IBM SPSS (version 22) for the objectives of the study and the related research questions. Table 1 summarises the main statistical techniques considered in this study.

Table 1. Data Analysis Techniques of Study

\begin{tabular}{ll}
\hline Data analysis & Purpose \\
\hline Descriptive analysis & To obtain the demographic profile of the respondents \\
Reliability analysis & $\begin{array}{l}\text { To measure the internal consistency between the measurement items } \\
\text { Factor analysis }\end{array}$ \\
$\begin{array}{l}\text { To assess the construct validity of data and to measure the degree to which the } \\
\text { measurement items gauge similar construct of interest }\end{array}$ \\
$\begin{array}{l}\text { Regression analysis } \\
\text { Toxamine the relationships of different constructs }\end{array}$
\end{tabular}

\section{RESULTS AND DISCUSSION}

This study tested Hypothesis 1 on the relationship between the dimensions of perceived value and revisit intention to the green resorts using simple regression analysis. The results revealed that $55.7 \%$ of the total variation in the revisit intention was explained by functional value $(\beta=0.0456, \mathrm{t}=10.706, \mathrm{p}=.000)$ and epistemic value $(\beta=0.0285, \mathrm{t}=5.781, \mathrm{p}=.000)$. Among all the constructs in this study, the functional value 
demonstrated the biggest influence in predicting the revisit intention where the obtained standardized beta recorded 0.456 . Thus, the functional value was deemed as an important predictor of revisit intention, which was followed by the epistemic value (standardized beta of 0.285 ). The findings also showed social value $(\beta=0.080, \mathrm{t}$ $=1.689, \mathrm{p}=.092)$ and emotional value $(\beta=0.037, \mathrm{t}=1.058, \mathrm{p}=.291)$. In this study, only $\mathrm{H} 1_{\mathrm{a}}$ and $\mathrm{H} 1_{\mathrm{c}}$ (functional value and epistemic value) were supported, whereas the other two hypotheses $\left(\mathrm{H} 1_{b}\right.$ and $\left.H 1_{d}\right)$ that involved social value and emotional value were rejected because the $p$-value was greater than 0.05 .

Table 2. Results of Simple Regression Analysis for Perceived Value and Revisit Intention

\begin{tabular}{|c|c|c|c|c|c|c|}
\hline \multirow{2}{*}{ Model } & \multirow[b]{2}{*}{ (Constant) } & \multicolumn{2}{|c|}{ Unstandardized Coefficient } & \multicolumn{3}{|c|}{ Standardized coefficient } \\
\hline & & $\begin{array}{l}B \\
1.420\end{array}$ & $\begin{array}{l}\text { Std. Error } \\
.220\end{array}$ & $B$ & $\begin{array}{l}\text { t-value } \\
6.440\end{array}$ & $\begin{array}{l}\text { Sig. } \\
.000\end{array}$ \\
\hline & Functional value & .476 & .044 & .456 & 10.706 & .000 \\
\hline & Social value & .060 & .035 & .080 & 1.689 & .092 \\
\hline & Epistemic value & .241 & .042 & .285 & 5.781 & .000 \\
\hline & Emotional value & .060 & .057 & .037 & 1.058 & 291 \\
\hline \multicolumn{7}{|c|}{$\begin{array}{l}R=0.747 \\
R^{2}=0.557 \\
F=140.084 \\
p<.001\end{array}$} \\
\hline
\end{tabular}

Among all the constructs embedded in this study, the functional value demonstrated the highest influence in predicting revisit intention, whereby the standardised beta was 0.456 . Hence, functional value is deemed as an important predictor of revisit intention, and followed by epistemic value (standardised beta $=0.285$ ). The findings displayed that social value $(\beta=0.080, \mathrm{t}=1.689, \mathrm{p}=.092)$ and emotional value $(\beta=0.037, \mathrm{t}=1.058, \mathrm{p}=.291)$ did not significantly influence revisit intention.

Concerning functional value, the results of this present research revealed that functional value had the most substantial influence on revisit intention. The findings agree with some studies, wherein the functional value is seen as a primary factor in guests' decision making. Accordingly, green resorts employ a range of green practices, such as the use of non-toxic materials, replacement of plastic utensils with glassware, and serving organic food, which is bound to enhance the environmental quality and to offer guests with improved air quality and ecofriendly linens, especially for those who suffer from allergies. Some researchers (see Kim et al., 2011; Lee et al., 2011) asserted that these green practices are critically conducive for guests to experience a safer and healthier environment. Denys and Mendes (2014) claimed that quality, variety, reliability, comfort, safety, and price are among the most common destination factors that are linked with functional value.

This study found epistemic value as the second most vital attribute among the dimensions of perceived value to influence the revisit intention, such as novelty, discovery, and learning about going green. In particular, epistemic value emerges when green resort guests have a desire for knowledge and are curious about the features of green resorts. The findings on epistemic value are concurrent with the findings reported by Biswas and Roy (2015) and Gonçalves et al. (2016), which highlighted the positive correlation between epistemic value and sustainable consumption behavior in India and green purchasing behavior, respectively. It reaffirms the expected key benefits of epistemic value for tourism experience (Williams \& Soutar, 2009). Lin and Huang (2012) revealed the significant influence of the epistemic value of green products (e.g., characteristics and design of products) on consumers' choice behavior. It is plausible as when customers are familiar with a brand, their sense of curiosity increases towards the new product, or they are willing to learn about the new product.

The study analysis suggests that both social and emotional values exerted no significant influence on revisit intention. It is in line with the study conducted by Wang (2004), which concluded the insignificance of social value in its relationship with purchasing or repurchasing green products and services. Han and Kim (2010), Chen and Tsai (2007) opposed the above findings, whereby the significance of social value on the decision to stay or intention to revisit was demonstrated instead. Williams and Soutar (2000) and Morgan et al. (2010) claimed that social value played a significant role in forming tourists' perceptions of their experience of staying in a green resort. Awuni and Du (2016) also propounded the influence of social needs and self-image on green purchase intention.

Interestingly, as previously revealed, emotional value exerted no influence on revisit intention despite the findings of prior studies revealed otherwise. In this present study, the respondents were asked if they felt positive or negative emotional values during their stay at the green resort. Interestingly, most customers felt that positive or negative emotional values did not influence their intention to revisit. On the contrary, resort guests who observed green certification as a sign of quality were more likely to opt for green lodging and displayed a willingness to pay a higher price to stay in green lodging (Millar \& Baloglu, 2011). Millar and Baloglu (2011) further 
pointed out that green customers would be motivated by the feel-good factor, such as the feeling of comfort, joyful, excited, pleasantly surprised, or calmness for contributing positive influence on the environment through their decision to stay in green lodging.

Based on SET, the exchange occurs when one receives a reward, and the benefits outweigh the costs. Perceived value influenced revisit intention to green resorts. Perceived value has been conceptualized as the difference between perceived benefit and perceived sacrifice. Typically, the benefit is derived from the perception of economic, social, and performance, whereas sacrifice is the price, time, effort, and risk. Perceived value reflects the prior experience of the different types of services and expected experience that affects the current and future value-in-context experience of the customers. Perceived value in this study had been viewed as the guests' overall assessment of their green resort experience based on their evaluation of consumption experience and their real experience. Hence, the guests were more likely to express favorable responses and may even revisit when they perceive a high value in the consumption made. In this case, the respondents perceived functional and epistemic values when staying in green resorts, which influenced their revisit intention to the green resort. This finding strengthens the guests' view that green resort experience in terms of benefits (quality, consistent service, worth for the price charged, discover experience something different, novelty experience, new and learn about being environment-friendly) from their stay in the green resort.

\section{CONCLUSION}

The empirical evidence obtained in this present study extends the existing body of knowledge by exploring the significance of perceived value in various dimensions about customers' intention to revisit green resorts. In terms of practical contributions, this study provides salient knowledge on four key dimensions (functional value, social value, emotional value, and epistemic value) related to perceived value in prompting customers' intention to revisit green resorts. This study provides significant insights and pertinent recommendations to the hospitality industry and clarifications on how customers develop their intention to revisit green resorts. Only by narrowing this specific knowledge gap could resort managers of these green resorts then be equipped to develop targeted marketing strategies to ensure existing customers' intention to revisit as well as to attract potential customers with various cultural backgrounds. Furthermore, it is pivotal to establish a clearly defined customer value for continuous operations of green resorts given the significance of perceived value in prompting customers' intention to revisit and extend such intention to friends, relatives, and others. This study explores the perceived value and customers' intention to revisit in the context of the green resort, which is particularly beneficial in the thematic green design concept, the marketing planning strategies, and the consumer recognition targets. With that, this cultural case study would like to propound the significance of understanding salient factors that encourage customers' intention to revisit green resorts, with considerations of developing specific service blueprints based on customers' demands to ensure a positive experience that instigate their intentions to revisit.

\section{REFERENCES}

Ali, F., Omar, R., \& Amin, M. (2013). An examination of the relationships between physical environment, perceived value, image and behavioural Intentions: A SEM approach towards Malaysian resort hotels. Journal of Hotel and Tourism Management, 27(2), 9-26.

Andreu, L., Kozak, M., Avci, N., \& Cifter, N. (2006). Market segmentation by motivations to travel: British tourists visiting Turkey. Journal of Travel \& Tourism Marketing, 19(1), 1-14.

Barber, N. A. (2014). Profiling the potential "green" hotel guest: Who are they and what do they want?. Journal of Hospitality \& Tourism Research, 38(3), 361-387.

Bohdanowicz, P. (2006). Environmental awareness and initiatives in the Swedish and Polish hotel industriessurvey results. International journal of hospitality management, 25(4), 662-682.

Chen, C. F., \& Tsai, D. (2007). How destination image and evaluative factors affect behavioral intentions?. Tourism management, 28(4), 1115-1122.

Corral-Verdugo, V., Bonnes, M., Tapia-Fonllem, C., Fraijo-Sing, B., Frías-Armenta, M., \& Carrus, G. (2009). Correlates of pro-sustainability orientation: The affinity towards diversity. Journal of Environmental Psychology, 29(1), 34-43. 
Dief, M. E., \& Font, X. (2010). The determinants of hotels' marketing managers' green marketing behaviour. Journal of sustainable tourism, 18(2), 157-174.

Fu, Y., \& Hu, B. (2011, May). The effects of low-carbon consumption on consumer perceived value in green hotels. In 2011 International Conference on Business Management and Electronic Information (Vol. 1, pp. 344-347). IEEE.

Global Industry Research Report. Retrieved from http:/www.ibisworld.com/industry/global/global-hotelsresorts.html. (accessed 11 February 2013)

Green Hotel Association (2008). What are Green Hotels? Retrieved from http:/l www.greenhotels.com/whatare.htm (accessed 10 May 2008).

Griskevicius, V., Tybur, J. M., \& Van den Bergh, B. (2010). Going green to be seen: status, reputation, and conspicuous conservation. Journal of personality and social psychology, 98(3), 392-404.

Ha, J., \& Jang, S. S. (2010). Effects of service quality and food quality: The moderating role of atmospherics in an ethnic restaurant segment. International journal of hospitality management, 29(3), 520-529.

Han, H., Hsu, L. T. J., \& Lee, J. S. (2009). Empirical investigation of the roles of attitudes toward green behaviors, overall image, gender, and age in hotel customers' eco-friendly decision-making process. International journal of hospitality management, 28(4), 519-528.

Han, H., Hsu, L. T. J., \& Sheu, C. (2010). Application of the theory of planned behavior to green hotel choice: Testing the effect of environmental friendly activities. Tourism management, 31(3), 325-334.

Han, H., \& Kim, Y. (2010). An investigation of green hotel customers' decision formation: Developing an extended model of the theory of planned behavior. International journal of hospitality management, 29(4), 659-668.

Han, H., Hsu, L. T. J., Lee, J. S., \& Sheu, C. (2011). Are lodging customers ready to go green? An examination of attitudes, demographics, and eco-friendly intentions. International Journal of Hospitality Management, 30(2), 345-355.

Holbrook, M. B., \& Corfman, K. P. (1985). Quality and value in the consumption experience: Phaedrus rides again. Perceived quality, 31(2), 31-57.

Hotel Online (2002). Consumer attitudes towards the role of hotels in environmental sustainability. Retrieved from http://www.hotel-online.com/News/PR20023rd/Jul02 IHEl.html (accessed 23 July 2002).

Hsiao, T. Y., Chuang, C. M., Kuo, N. W., \& Yu, S. M. F. (2014). Establishing attributes of an environmental management system for green hotel evaluation. International Journal of Hospitality Management, 36(1), 197-208.

Hu, H. H., Kandampully, J., \& Juwaheer, T. D. (2009). Relationships and impacts of service quality, perceived value, customer satisfaction, and image: an empirical study. The service industries journal, 29(2), 111-125.

Holbrook, M. B. (1999). Consumer value: a framework for analysis and research. Routledge: London.

Inbakaran, R., Jackson, M., \& Chhetri, P. (2004). Segmentation of resort tourists: A study on profile differences in selection, satisfaction, opinion and preferences. In New Zealand Tourism and Hospitality Research Conference 2004. Victoria University of Wellington.

Jamal, S. A., Othman, N. A., \& Muhammad, N. M. N. (2011). Tourist perceived value in a community-based homestay visit: An investigation into the functional and experiential aspect of value. Journal of Vacation Marketing, 17(1), 5-15.

Jeong, E. H., \& Jang, S. C. (2010). Effects of restaurant green practices: which practices are important and effective? Caesars Hospitality Research Summit of Emerging issues and trends in hospitality and tourism, 13(1), 23. 
Kim, K., Noh, J., \& Jogaratnam, G. (2007). Multi-destination segmentation based on push and pull motives: Pleasure trips of students at a US university. Journal of Travel \& Tourism Marketing, 21(2-3), 19-32.

Kim, Y. H., Kim, M., \& Goh, B. K. (2011). An examination of food tourist's behavior: Using the modified theory of reasoned action. Tourism management, 32(5), 1159-1165.

Kotler, P., Bowen, J. T., Makens, J., \& Baloglu, S. (1999). Marketing for Hospitality and Tourism, 2nd ed., Prentice-Hall, Upper Saddle River, NJ.

Kozak, M., \& Rimmington, M. (2000). Tourist satisfaction with Mallorca, Spain, as an off-season holiday destination. Journal of travel research, 38(3), 260-269.

Kuo, Y. F., Wu, C. M., \& Deng, W. J. (2009). The relationships among service quality, perceived value, customer satisfaction, and post-purchase intention in mobile value-added services. Computers in human behavior, 25(4), 887-896.

Lee, M., Han, H., \& Willson, G. (2011). The role of expected outcomes in the formation of behavioral intentions in the green-hotel industry. Journal of Travel \& Tourism Marketing, 28(8), 840-855.

Maibach, E. (1993). Social marketing for the environment: Using information campaigns to promote environmental awareness and behavior change. Health promotion international, 8(3), 209-224.

Manaktola, K., \& Jauhari, V. (2007). Exploring consumer attitude and behaviour towards green practices in the lodging industry in India. International Journal of Contemporary Hospitality Management, 19(5), 364377.

Millar, M., \& Baloglu, S. (2011). Hotel guests' preferences for green guest room attributes. Cornell Hospitality Quarterly, 52(3), 302-311.

Morgan, M., Lugosi, P., \& Ritchie, J. R. B. (2010). The tourism and leisure experience consumer and managerial perspectives. MPG Books Group Ltd. Great Britain.

Noypayak, W. (2009). Value dimensions of Thailand as perceived by U.K. tourists, RU. International Journal, 3(1), 141-154.

Pandža, B. I. (2013). Tourist perceived value, relationship to satisfaction, and behavioural intentions: the example of the croatian tourist destination dubrovnik. Journal of Travel Research, 54(1), 122-134.

Petrick, J. F. (2002). Development of a multi-dimensional scale for measuring the perceived value of a service. Journal of leisure research, 34(2), 119-134.

Petrick, J. F. (2004). Are loyal visitors desired visitors?. Tourism management, 25(4), 463-470.

Pirani, S. I., \& Arafat, H. A. (2014). Solid waste management in the hospitality industry: A review. Journal of Environmental Management, 146, 320-336.

Ramayah, T., Lee, J. W. C., \& Mohamad, O. (2010). Green product purchase intention: Some insights from a developing country. Resources, conservation and recycling, 54(12), 1419-1427.

Ritov, I., \& Kahnemann, D. (1997). How people value the environment: attitudes versus economic value, in Bazermann, M.H., Messick, D. M., Tenbrunsel, A. E. and Wade-Benzoni, K.A. (Eds), Environment, Ethics, and Behavior, The New Lexington Press, San Francisco, CA, 33-51.

Robinot, E., \& Giannelloni, F. L. (2010). Do hotels 'green' attributes contribute to customer satisfaction?. Journal of Service Marketing, 24(2), 157-169.

Russell, J. A., \& Pratt, G. (1980). A description of the affective quality attributed to environments. Journal of personality and social psychology, 38(2), 311-322.

Ryu, K., Lee, H. R., \& Kim, W. G. (2012). The influence of the quality of the physical environment, food, and service on restaurant image, customer perceived value, customer satisfaction, and behavioral intentions. International journal of Contemporary Hospitality Management, 24(2), 200-223. 
Sandstrom, S., Edvardsson, B., Kristensson, P., \& Magnusson, P. (2008). Value in use through service experience. Managing Service Quality, 18(2), 112-126.

Schiffman, L. G., \& Kanuk, L.L. (1987). Consumer behavior (3 ${ }^{\text {rd }}$ Ed.). Englewood Cliffs, New Jersey: PrenticeHall.

Sheth, J. N., Newman, B. I., \& Gross, B. L. (1991). Why we buy what we buy: A theory of consumption values. Journal of business research, 22(2), 159-170.

Shrum, L. J., McCarty, J. A., \& Lowrey, T. M. (1995). Buyer characteristics of the green consumer and their implications for advertising strategy. Journal of advertising, 24(2), 71-82.

Sweeney, J. C., \& Soutar, G. N. (2001). Consumer perceived value: The development of a multiple item scale. Journal of retailing, 77(2), 203-220.

Swinyard, W. R. (1993). The effects of mood, involvement, and quality of store experience on shopping intentions. Journal of consumer research, 20(2), 271-280.

Tapachai, N., \& Waryszak, R. (2000). An examination of the role of beneficial image in tourist destination selection. Journal of travel research, 39(1), 37-44.

Um, S., Chon, K., \& Ro, Y. H. (2006). Antecedents of revisit intention. Annals of Tourism Research, 33(4), 11411158.

Wilkie, W. L. (1994). Consumer behavior ( $3^{\text {rd }}$ Ed.). New York: John Wiley \& Sons.

Williams, P., \& Soutar, G. N. (2000). Dimensions of customer value and the tourism experience: an exploratory study. Retrived from http://smib.vuw.ac.nz:8081/www/ANZMAC2000/CDsite/papers/w/William 3.pdf.

Yang, Y., \& Chan, A. (2010). A hierarchical approach to measure service performance in the resort hotel's service encounters. Journal of Tourism, Hospitality \& Culinary Arts (JTHCA), 2(1).

Yang, J., \& Youngtae, K. (2015). Developing multi-dimensional green value: extending Social Exchange Theory to explore customers' purchase intention in green hotels - evidence from Korea. International Journal of Contemporary Hospitality Management, 27(2), 308-334.

Yoon, Y., \& Uysal, M. (2005). An examination of the effects of motivation and satisfaction on destination loyalty: a structural model. Tourism management, 26(1), 45-56.

Zeithaml, V. A. (1988). Consumer perceptions of price, quality, and value: a means-end model and synthesis of evidence. Journal of marketing, 52(3), 2-22. 